\title{
Alterations of growth performance, hematological parameters, and plasma constituents in the sablefish, Anoplopoma fimbria depending on ammonia concentrations
}

\author{
Jun-Hwan Kim ${ }^{1}$, Hee-Ju Park², In-Ki Hwang ${ }^{2}$, Jae-Min Han², Do-Hyung Kim² ${ }^{2}$ Chul Woong Oh ${ }^{3}$, Jung Sick Lee \\ and Ju-Chan Kang ${ }^{2 *}$
}

\begin{abstract}
Juvenile Anoplopoma fimbria (mean length $16.8 \pm 2.2 \mathrm{~cm}$, and mean weight $72.8 \pm 5.4 \mathrm{~g}$ ) were exposed for 2 months with different levels of ammonia $(0,0.25,0.50,0.75,1.00$, and $1.25 \mathrm{mg} / \mathrm{L})$. Growth performances such as daily length gain, daily weight gain, condition factor, and hepatosomatic index were significantly decreased by ammonia exposure. Hematological parameters such as red blood cell (RBC) count, hematocrit, and hemoglobin were also significantly decreased. In plasma inorganic components, calcium and magnesium were significantly decreased by ammonia exposure. In plasma organic components, there was no alteration in cholesterol and total protein. In enzyme plasma components, glutamic oxalate transaminase (GOT) and glutamic pyruvate transaminase (GPT) were significantly increased. The results of this study indicated that ammonia exposure can induce significant growth reduction and blood biochemistry alterations of $A$. fimbria.
\end{abstract}

Keywords: Sablefish, Ammonia, Growth performance, Hematological parameters, Plasma components

\section{Background}

In Korea, aquaculture is a major industry in food security dimension because it can supply high-quality protein to the public by stably breeding aquatic organisms. However, ammonia hypergenesis by high density breeding in aquaculture environment is a critical environmental toxic factor to induce death. Exposure to excessive ammonia in aquatic animals induces depolarization in neuron because increased $\mathrm{NH}_{4}^{+}$displaces $\mathrm{K}^{+}$, which results in cell death in central nervous system. Therefore, it induces convulsions, coma, and death by the cell death (Thangam et al. 2014). In addition, acute ammonia exposure induces gill ventilation increase, equilibrium loss, convulsions, ionic balance failure, and hyper-excitability in aquatic animals (Kim et al. 2015).

\footnotetext{
*Correspondence: jckang@pknu.ac.kr

2Department of Aquatic Life Medicine, Pukyong National University, Busan, Korea

Full list of author information is available at the end of the article
}

Growth factor in aquaculture is one of the most basic and critical parameters to assess toxic effects by harmful substances in aquaculture environment. In fish exposed to toxic substances, growth performance is generally decreased by energy transition from use for growth and development to use for tissue damage recovery (Wendelaar Bonga, 1997). In aquatic environment, excessive ammonia concentrations can be accumulated in body fluids in fish, which results in growth inhibition, tissue erosion and degeneration, immune suppression, and high mortality (Liang et al., 2015).

Hematological and biochemical parameters in fish can be a critical indicator to assess alterations in circulatory system by toxic substances in external environment (Vinodhini and Narayanan, 2009). Ammonia especially affects hematological parameters in fish by blocking oxygen transfer from gill to blood (Thangam et al. 2014).

Sablefish, Anoplopoma fimbria used in this study is recognized as a high value fish species around the globe. 
In liberalization trend of the world market, aquatic products are also involved in the trend. Therefore, development in aquaculture of a high value fish species is urgent. The purpose of this study was to assess toxic effects of $A$. fimbria exposed to ammonia a part of complete sablefish culture, and to build standard breeding guidelines of sablefish aquaculture.

\section{Methods}

\section{Experimental fish and conditions}

Juvenile sablefish were obtained from Troutlodge Inc. in USA. During the acclimation period, the fish were fed diet twice daily and maintained on a 24-h dark cycle and constant condition at all times (Table 1). After acclimatization, 72 fish (body length, $16.8 \pm 2.2 \mathrm{~cm}$; body weight, $72.8 \pm 5.4 \mathrm{~g}$ ) were randomly selected for the study. The acclimation period commenced once the final temperature had been sustained for $24 \mathrm{~h}$ and animals were feeding, while showing no sign of stress. Ammonia exposure took place in tanks containing six fish per treatment group. Ammonia chloride $\left(\mathrm{NH}_{4} \mathrm{Cl}\right)$ (Sigma, St. Louis, $\mathrm{MO}$, USA) solution was dissolved in the respective tanks. The ammonia concentrations in the tanks were $0,0.25,0.50$, $0.75,1.00$, and $1.25 \mathrm{mg} / \mathrm{L}$, and actual ammonia concentrations are demonstrated in Table 2. Diluted $100 \mathrm{mg} / \mathrm{L}$ ammonia chloride $\left(\mathrm{NH}_{4} \mathrm{Cl}\right)$ in $20 \mathrm{~L}$ glass tank to make respective concentrations $(50,0.25 \mathrm{mg} / \mathrm{L}, 100 \mathrm{ml}$; $0.50 \mathrm{mg} / \mathrm{L}, 150 \mathrm{ml} ; 0.75 \mathrm{mg} / \mathrm{L}, 200 \mathrm{ml} ; 1.00 \mathrm{mg} / \mathrm{L}, 250 \mathrm{ml}$; $1.25 \mathrm{mg} / \mathrm{L}$ ). After the exposure experiment, feed was given at a rate of $2 \%$ body weight daily (as two $1 \%$ meals per day). There was no water flow rate. The tank water was thoroughly exchanged once per 2 days and made the same concentration in the respective $500 \mathrm{~L}$ circular tank. At the end of each period (at 1 and 2 months), animals were anesthetized in buffered 3-aminobenzoic acid ethyl ester methanesulfonate (Sigma Chemical, St. Louis, MO).

\section{Growth}

The weight and length of sablefish was measured just before exposure, at 1 and 2 months. Daily length gain, daily weight gain, condition factor, and hepatosomatic index (HSI) were calculated by the following method.

Table 1 The chemical components of seawater and experimental condition used in the experiments

\begin{tabular}{lc}
\hline Item & \multicolumn{1}{c}{ Value } \\
\hline Temperature $\left({ }^{\circ} \mathrm{C}\right)$ & $13.0 \pm 1.0$ \\
$\mathrm{pH}$ & $8.2 \pm 0.5$ \\
Salinity $(\%)$ & $33.5 \pm 0.6$ \\
Dissolved oxygen $(\mathrm{mg} / \mathrm{L})$ & $7.8 \pm 0.5$ \\
Chemical oxygen demand $(\mathrm{mg} / \mathrm{L})$ & $1.21 \pm 0.14$ \\
\hline
\end{tabular}

Table 2 Analyzed waterborne ammonia concentration from each source

\begin{tabular}{lllllll}
\hline $\begin{array}{l}\text { Waterborne ammonia } \\
\text { concentration (mg/L) }\end{array}$ & & & & & & \\
\hline $\begin{array}{l}\text { Waterborne ammonia } \\
\text { concentrations }\end{array}$ & 0 & 0.25 & 0.50 & 0.75 & 1.00 & 1.25 \\
Actual ammonia & $0.02 \pm$ & $0.28 \pm$ & $0.57 \pm$ & $0.81 \pm$ & $1.04 \pm$ & $1.32 \pm$ \\
concentrations & 0.01 & 0.07 & 0.14 & 0.26 & 0.32 & 0.27 \\
\hline
\end{tabular}

Daily growth gain $=W_{\mathrm{f}}-W_{\mathrm{i}} /$ day

$\left(W_{\mathrm{f}}=\right.$ Final length or weight, $\mathrm{W}_{\mathrm{i}}=$ Initial length or weight $)$

Condition factor $(\%)=\left(W / L^{3}\right) \times 100$

$(W=\operatorname{weight}(\mathrm{g}), L=\operatorname{length}(\mathrm{cm}))$

HSI $=($ liver weight $/$ total fish weight $) \times 100$

\section{Blood samples and hematological assay}

Blood samples were collected within 35-40 s through the caudal vein of the fish in 1-ml disposable heparinized syringes at the end of 1 and 2 months. The blood samples were kept at $4{ }^{\circ} \mathrm{C}$ until the blood parameters were completely studied. The total red blood cell (RBC) count, hemoglobin $(\mathrm{Hb})$, concentration, and hematocrit $(\mathrm{Ht})$ value were determined immediately. Total RBC counts were counted using optical microscope with hemo-cytometer (Improved Neubauer, Germany) after diluted by Hendrick's diluting solution. The Hb concentration was determined using Cyan-methemoglobin technique (Asan Pharm. Co., Ltd.). The Ht value was determined by the microhematocrit centrifugation technique. The blood samples were centrifuged to separate plasma from blood samples at $3000 \mathrm{~g}$ for $5 \mathrm{~min}$ at $4{ }^{\circ} \mathrm{C}$. The plasma samples were analyzed for inorganic substances, organic substances, and enzyme activity using clinical kit (Asan Pharm. Co.,Ltd.). In inorganic substances assay, calcium and magnesium were analyzed by the ocresolphthalein-complexon technique and xylidyl blue technique. In organic substances assay, cholesterol and total protein were analyzed by enzyme method and by biuret technique. In enzyme activity assay, glutamic oxalate transaminase (GOT) and glutamic pyruvate transaminase (GPT) were analyzed by Kind-king technique.

\section{Statistical analysis}

The experiment was conducted in exposure periods for 2 months and performed triplicate. Statistical analyses were performed using the SPSS/PC+ statistical package (SPSS Inc, Chicago, IL, USA). Significant differences between groups were identified using one-way ANOVA and Tukey's test for multiple comparisons. The significance level was set at $P<0.05$. 

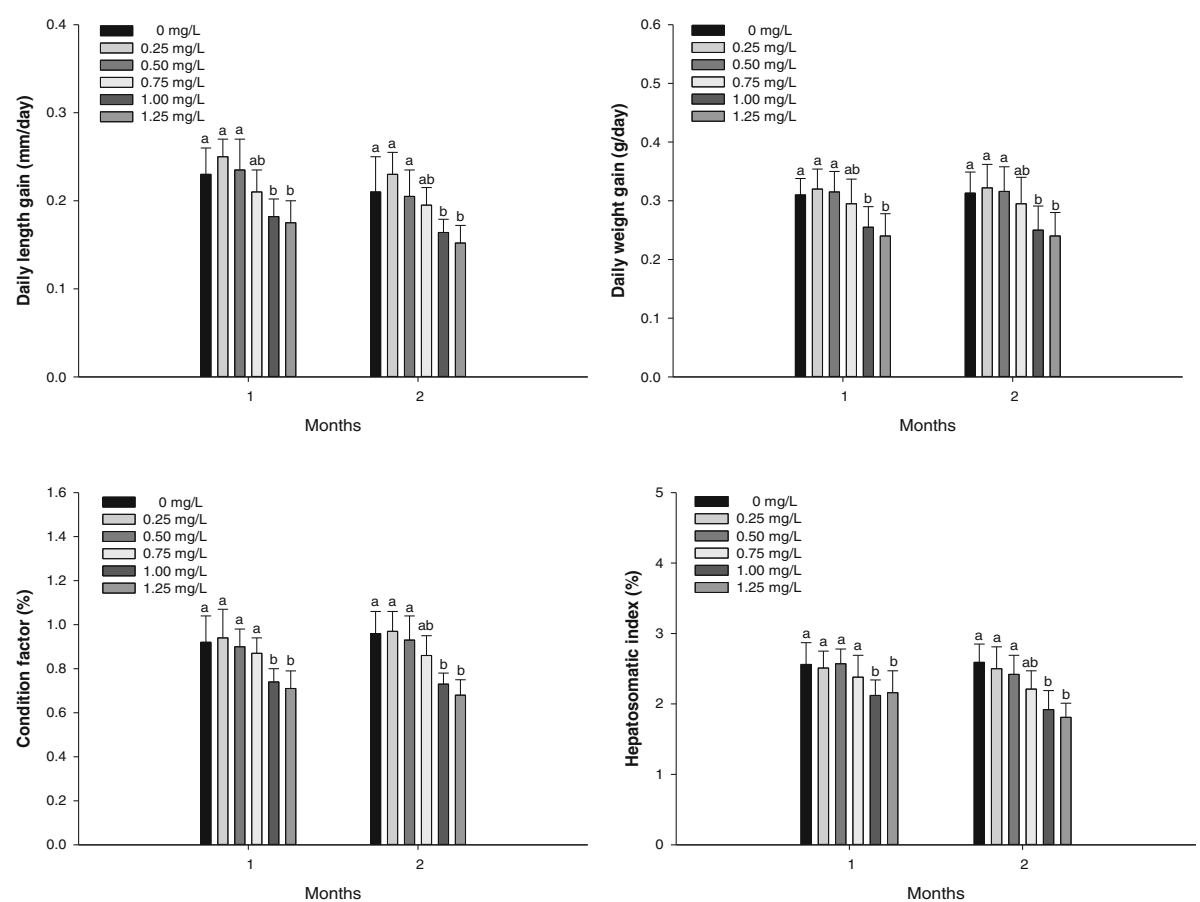

Fig. 1 Daily length gain, daily weight gain, condition factor, and hepatosomatic index of sablefish, Anoplopoma fimbria exposed to ammonia for 2 months. Vertical bar denotes a standard error. Values with different superscript are significantly different at 1 and 2 months $(P<0.05)$ as determined by Tukey's multiple range test

\section{Results}

\section{Growth}

No mortality was observed for the exposure periods. The growth performance, condition factor, and hepatosomatic index of A. fimbria is demonstrated in Fig. 1. Significant decreases in daily length gain and daily weight gain were observed at ammonia exposure greater than $1.00 \mathrm{mg} / \mathrm{L}$ both in 1 and 2 months. Condition factor was significantly decreased at ammonia exposure greater than $1.00 \mathrm{mg} / \mathrm{L}$ both in 1 and 2 months. Hepatosomatic index was also significantly decreased at ammonia exposure greater than $1.00 \mathrm{mg} / \mathrm{L}$ both in 1 and 2 months. However, there was no change in daily length, daily weight gain, and condition factor and hepatosomatic index from 0 to $0.75 \mathrm{mg} / \mathrm{L}$ ammonia exposure after 1 and 2 months.

\section{Hematological parameters}

RBC count, hematocrit value, and hemoglobin concentration of A. fimbria exposed to different concentrations of waterborne ammonia are demonstrated in Fig. 2. RBC count was significantly decreased at ammonia exposure greater than $1.00 \mathrm{mg} / \mathrm{L}$ in 1 month and greater than $0.75 \mathrm{mg} / \mathrm{L}$ in 2 months. Hematocrit value was significantly decreased at ammonia exposure greater than $1.00 \mathrm{mg} / \mathrm{L}$ in 1 month and greater than $0.75 \mathrm{mg} / \mathrm{L}$ in 2 months. Hemoglobin concentration was significantly
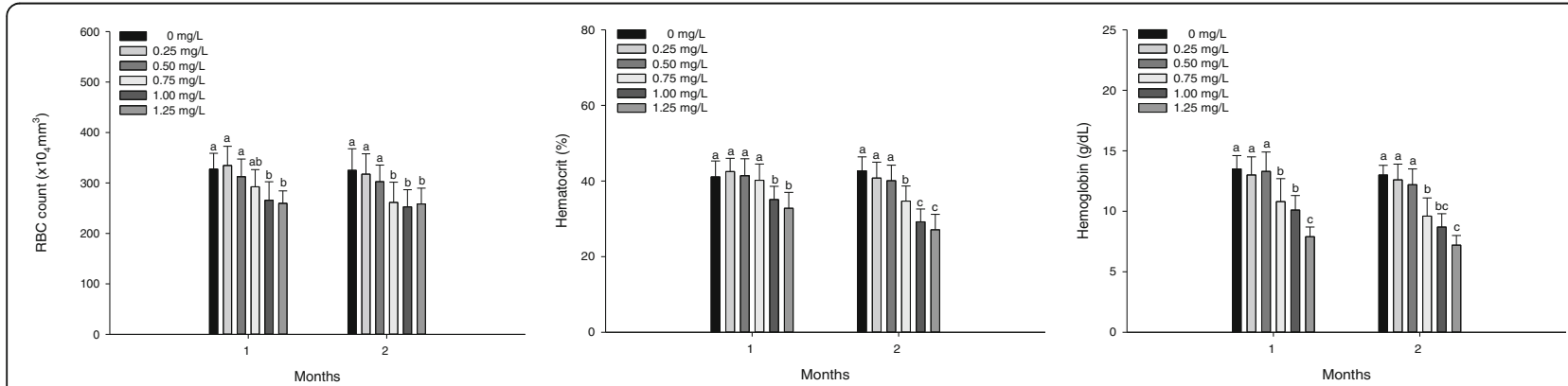

Fig. 2 RBC count, hematocrit, and hemoglobin of sablefish, Anoplopoma fimbria exposed to ammonia for 2 months. Vertical bar denotes a standard error. Values with different superscript are significantly different at 1 and 2 months $(P<0.05)$ as determined by Tukey's multiple range test 
Table 3 Changes of inorganic plasma components in sablefish, Anoplopoma fimbria exposed to ammonia for 2 months

\begin{tabular}{|c|c|c|c|c|c|c|c|}
\hline \multirow[t]{2}{*}{ Parameters } & \multirow{2}{*}{$\begin{array}{l}\text { Period } \\
\text { (month) }\end{array}$} & \multicolumn{6}{|c|}{ Ammonia (mg/L) } \\
\hline & & 0 & 0.25 & 0.50 & 0.75 & 1.00 & 1.25 \\
\hline \multirow{2}{*}{$\begin{array}{l}\text { Calcium } \\
\text { (mg/dL) }\end{array}$} & 1 & $1.84 \pm 0.23^{\mathrm{a}}$ & $1.81 \pm 0.26^{\mathrm{a}}$ & $1.75 \pm 0.31^{\mathrm{a}}$ & $1.71 \pm 0.30^{\mathrm{ab}}$ & $1.59 \pm 0.25^{b}$ & $1.55 \pm 0.21^{b}$ \\
\hline & 2 & $1.81 \pm 0.27^{a}$ & $1.78 \pm 0.23^{\mathrm{a}}$ & $1.62 \pm 0.25^{\mathrm{ab}}$ & $1.64 \pm 0.21^{\mathrm{ab}}$ & $1.49 \pm 0.27^{b}$ & $1.42 \pm 0.24^{b}$ \\
\hline \multirow{2}{*}{$\begin{array}{l}\text { Magnesium } \\
\text { (mg/dL) }\end{array}$} & 1 & $3.46 \pm 0.42^{\mathrm{a}}$ & $3.51 \pm 0.32^{\mathrm{a}}$ & $3.41 \pm 0.27^{\mathrm{a}}$ & $3.29 \pm 0.35^{\mathrm{ab}}$ & $2.89 \pm 0.22^{b}$ & $2.95 \pm 0.32^{b}$ \\
\hline & 2 & $3.41 \pm 0.36^{\mathrm{a}}$ & $3.46 \pm 0.38^{\mathrm{a}}$ & $3.28 \pm 0.41^{\mathrm{ab}}$ & $3.06 \pm 0.25^{b}$ & $2.74 \pm 0.30^{b}$ & $2.71 \pm 0.24^{b}$ \\
\hline
\end{tabular}

Values are mean \pm SE. Values with different superscript are significantly different at 1 and 2 months $(P<0.05)$ as determined by Tukey's multiple range test

decreased at ammonia exposure greater than $0.75 \mathrm{mg} / \mathrm{L}$ in 1 and 2 months.

\section{Plasma components}

Plasma inorganic components of $A$. fimbria are demonstrated in Table 3. Calcium was significantly decreased at ammonia exposure greater than $1.00 \mathrm{mg} / \mathrm{L}$ in 1 and 2 months. Magnesium was also significantly decreased at ammonia exposure greater than $1.00 \mathrm{mg} / \mathrm{L}$ in 1 month and greater than 0.75 in 2 months. Plasma organic components are demonstrated in Table 4. No alterations in cholesterol and total protein were observed by waterborne ammonia exposure. Plasma enzyme components are demonstrated in Table 5. GOT was significantly increased at ammonia exposure greater than $1.00 \mathrm{mg} / \mathrm{L}$ in 1 month and greater than 0.75 in 2 months. GPT was also significantly increased at ammonia exposure greater than $1.00 \mathrm{mg} / \mathrm{L}$ in 1 month and greater than 0.75 in 2 months.

\section{Discussion}

Ammonia exposure to fish is a critical environmental limited factor to inhibit growth performance by decreasing feed intake and feed utilization (Foss et al., 2003). Many authors reported that high concentrations of ammonia exposure induced growth inhibition of spotted wolfish, Anarhichas minor Olafsen (Foss et al., 2003), turbot, Scophthalmus maximus (Foss et al., 2009), Atlantic halibut, Hippoglossus hippoglossus (Paust et al., 2011). In this study, high concentrations of ammonia induced a significant decrease in growth of sablefish, A. fimbria, which may be due to energy transition from growth and development to detoxification. Hepatosomatic index (HSI) is considered as a critical indicator to evaluate health status by toxic substance exposure (Datta et al., 2007), and HSI of sablefish, A. fimbria was significantly decreased by ammonia exposure.

Blood cells in fish are generated from hematopoietic tissues of kidney and spleen, and changes in hematological parameters indicate physiological effects by stress responses (Das et al., 2004). Jeney et al. (1992) suggest that high levels of ammonia exposure induce oxygen-free condition by increasing affinity of hemoglobin to combine with ammonia molecules, thereby elevating ammonia concentration in blood. Knoph and Thorud (1996) reported a significant decrease in RBC count and hematocrit of Atlantic salmon, Salmo salar exposed to ammonia. Das et al. (2004) also reported a significant decrease in hemoglobin of Mrigal carp, Cirrhinus cirrhosus exposed to ammonia. In this study, ammonia exposure caused a significant decrease in RBC count, hematocrit, and hemoglobin of sablefish, $A$. fimbria, which may be due to hematopoietic cell damage according to hypoxic status by ammonia exposure.

Calcium and magnesium in plasma inorganic components are critical indicators of osmotic pressure alterations, and these can be increased or decreased by environmental changes (Hur et al., 2001). Person-Le Ruyet et al., (2003) reported that ammonia exposure to turbot, Scophthalmus maximus induced changes in osmotic pressure by altering $\mathrm{Na}^{+}, \mathrm{Cl}^{-}, \mathrm{K}^{+}, \mathrm{Ca}^{2+}$ concentrations in plasma. In this study, calcium and magnesium in sablefish, A. fimbria were significantly decreased by ammonia exposure, which indicate that ammonia exposure affected the osmotic ion regulation of sablefish. Cholesterol and total protein of plasma organic components in fish have been considered as a major component to assess fish health. However, there

Table 4 Changes of organic plasma components in sablefish, Anoplopoma fimbria exposed to ammonia for 2 months

\begin{tabular}{|c|c|c|c|c|c|c|c|}
\hline \multirow[t]{2}{*}{ Parameters } & \multirow{2}{*}{$\begin{array}{l}\text { Period } \\
\text { (month) }\end{array}$} & \multicolumn{6}{|c|}{ Ammonia (mg/L) } \\
\hline & & 0 & 0.25 & 0.50 & 0.75 & 1.00 & 1.25 \\
\hline \multirow{2}{*}{$\begin{array}{l}\text { Cholesterol } \\
(\mathrm{mg} / \mathrm{dL})\end{array}$} & 1 & $131.5 \pm 20.5^{a}$ & $139.1 \pm 18.2^{a}$ & $140.5 \pm 21.3^{a}$ & $137.2 \pm 16.8^{a}$ & $142.2 \pm 21.1^{a}$ & $146.2 \pm 18.3^{a}$ \\
\hline & 2 & $135.1 \pm 17.1^{a}$ & $131.5 \pm 17.1^{a}$ & $138.2 \pm 17.1^{a}$ & $143.2 \pm 21.3^{a}$ & $148.3 \pm 18.3^{a}$ & $142.6 \pm 20.2^{a}$ \\
\hline \multirow{2}{*}{$\begin{array}{l}\text { Total protein } \\
(\mathrm{g} / \mathrm{dL})\end{array}$} & 1 & $4.42 \pm 0.53^{a}$ & $4.35 \pm 0.39^{a}$ & $4.26 \pm 0.45^{a}$ & $4.51 \pm 0.48^{a}$ & $4.33 \pm 0.37^{a}$ & $4.59 \pm 0.41^{a}$ \\
\hline & 2 & $4.36 \pm 0.47^{a}$ & $4.56 \pm 0.35^{\mathrm{a}}$ & $4.37 \pm 0.31^{a}$ & $4.62 \pm 0.52^{a}$ & $4.24 \pm 0.45^{a}$ & $4.39 \pm 0.51^{\mathrm{a}}$ \\
\hline
\end{tabular}

Values are mean \pm SE. Values with different superscript are significantly different at 1 and 2 months $(P<0.05)$ as determined by Tukey's multiple range test 
Table 5 Changes of enzymatic plasma components in sablefish, Anoplopoma fimbria exposed to ammonia for 2 months

\begin{tabular}{|c|c|c|c|c|c|c|c|}
\hline \multirow[t]{2}{*}{ Parameters } & \multirow{2}{*}{$\begin{array}{l}\text { Period } \\
\text { (month) }\end{array}$} & \multicolumn{6}{|c|}{ Ammonia (mg/L) } \\
\hline & & 0 & 0.25 & 0.50 & 0.75 & 1.00 & 1.25 \\
\hline \multirow{2}{*}{$\begin{array}{l}\text { GOT } \\
\text { (karmen unit) }\end{array}$} & 1 & $2.67 \pm 0.33^{a}$ & $2.72 \pm 0.29^{a}$ & $2.75 \pm 0.35^{a}$ & $2.81 \pm 0.28^{\mathrm{a}}$ & $3.36 \pm 0.41^{b}$ & $3.45 \pm 0.37^{b}$ \\
\hline & 2 & $2.72 \pm 0.25^{\mathrm{a}}$ & $2.61 \pm 0.32^{\mathrm{a}}$ & $2.91 \pm 0.21^{\mathrm{ab}}$ & $3.24 \pm 0.32^{b}$ & $3.46 \pm 0.40^{\mathrm{bc}}$ & $3.62 \pm 0.41^{c}$ \\
\hline \multirow{2}{*}{$\begin{array}{l}\text { GPT } \\
\text { (karmen unit) }\end{array}$} & 1 & $1.72 \pm 0.24^{a}$ & $1.79 \pm 0.19^{a}$ & $1.84 \pm 0.18^{\mathrm{a}}$ & $1.93 \pm 0.26^{\mathrm{ab}}$ & $2.19 \pm 0.31^{b}$ & $2.28 \pm 0.27^{b}$ \\
\hline & 2 & $1.75 \pm 0.28^{a}$ & $1.82 \pm 0.23^{\mathrm{a}}$ & $1.99 \pm 0.28^{\mathrm{a}}$ & $2.23 \pm 0.31^{b}$ & $2.41 \pm 0.35^{c}$ & $2.40 \pm 0.35^{c}$ \\
\hline
\end{tabular}

Values are mean \pm SE. Values with different superscript are significantly different at 1 and 2 months $(P<0.05)$ as determined by Tukey's multiple range test

was no significant alteration in sablefish, A. fimbria. GOT and GPT in enzymatic plasma components can be easily increased by hepatic tissue damage, and these are used to evaluate hepatic tissue damage (Agrahari et al., 2007). Le Ruyet et al. (1998) reported that a significant increase in GOT and GPT of turbot, Scophthalmus maximus and seabream, Sparus aurata exposed to ammonia. In this study, GOP and GPT in sablefish, A. fimbria were significantly increased by ammonia exposure, which may be due to hepatic tissue damage by ammonia.

\section{Conclusion}

The results of this study indicate that ammonia exposure at the higher than proper concentrations affected growth performance and hematological parameters of sablefish, A. fimbria, and these changes should influence the health of sablefish, A. fimbria. In conclusion, ammonia concentrations at the higher than $0.75 \mathrm{mg} / \mathrm{L}$ can affect various physiological effects of sablefish, A. fimbria, and the high concentrations of ammonia exposure require special attention in sablefish aquaculture. In addition to this environmental study, various environmental standards should be established for stable sablefish aquaculture.

\section{Abbreviations}

GOT: Glutamic oxalate transaminase; GPT: Glutamic pyruvate transaminase; HIS: Hepatosomatic index; RBC: Red blood cell

\section{Acknowledgements}

This research was a part of the project titled 'Development of practical techniques for the artificial seeding production of sablefish', funded by the MOF, Korea.

\section{Authors' contributions}

$\mathrm{HJ}, \mathrm{IK}$, and JM carried out the environmental toxicity studies and manuscript writing. $\mathrm{JH}, \mathrm{DH}, \mathrm{CW}$, and JS participated in the design of the study and data analysis. JC participated in its design and coordination and helped to draft the manuscript. All authors read and approved the final manuscript.

\section{Competing interests}

The authors declare that they have no competing interests.

\section{Consent for publication}

Not applicable

\section{Ethics approval and consent to participate}

All experimental animals used in this study were maintained under a protocol approved by the Institutional Animal Care and Use Committee of the Pukyong National University.
Disclosure

The dataset(s) supporting the conclusions of this article is not included in the article.

\section{Publisher's Note}

Springer Nature remains neutral with regard to jurisdictional claims in published maps and institutional affiliations.

\section{Author details}

${ }^{1}$ West Sea Fisheries Research Institute, National Institute of Fisheries Science, Incheon, Korea. ${ }^{2}$ Department of Aquatic Life Medicine, Pukyong National University, Busan, Korea. ${ }^{3}$ Department of Marine Biology, Pukyong National University, Busan, Korea. ${ }^{4}$ Department of Aqualife Medicine, Chonnam National University, Yeosu, Korea.

Received: 5 November 2016 Accepted: 17 March 2017

Published online: 24 March 2017

\section{References}

Agrahari S, Pandey KC, Gopal K. Biochemical alteration induced by monocrotophos in the blood plasma of fish, Channa punctatus (Bloch). Pestic Biochem Physiol. 2007:88:268-72.

Das PC, Ayyappan S, Jena JK, Das BK. Acute toxicity of ammonia and its sublethal effects on selected haematological and enzymatic parameters of mrigal, Cirrhinus mrigala (Hamilton). Aquac Res. 2004;35:134-43.

Datta S, Saha DR, Ghosh D, Majumdar T, Bhattacharya S, Mazumder S. Sub-lethal concentration of arsenic interferes with the proliferation of hepatocytes and induces in vivo apoptosis in Clarias batrachus L. Comp Biochem Physiol C Toxicol Pharmacol. 2007;145:339-49.

Foss A, Evensen TH, Vollen T, Øiestad V. Effects of chronic ammonia exposure on growth and food conversion efficiency in juvenile spotted wolffish. Aquaculture. 2003;228:215-24.

Foss A, Imsland AK, Roth B, Schram E, Stefansson SO. Effects of chronic and periodic exposure to ammonia on growth and blood physiology in juvenile turbot (Scophthalmus maximus). Aquaculture. 2009;296:45-50.

Hur JW, Chang YJ, Lim HK, Lee BK. Stress responses of cultured fishes elicited by water level reduction in rearing tank and fish transference during selection process. J Korean Fish Soc. 2001;34:465-72.

Jeney G, Nemcsok J, Zs J, Olah J. Acute effect of sublethal ammonia concentrations on common carp (Cyprinus carpio L.). II Effect of ammonia on blood plasma transminases (GOT, GPT), G1DH enzyme activity, and ATP value. Aquaculture. 1992;104:149-56.

Kim SH, Kim JH, Park MA, Hwang SD, Kang JC. The toxic effects of ammonia exposure on antioxidant and immune responses in Rockfish, Sebastes schlegelii during thermal stress. Environ Toxicol Pharmacol. 2015;40:954-9.

Knoph MB, Thorud K. Toxicity of ammonia to Atlantic salmon (Salmo salar L.) in seawater-Effects on plasma osmolality, ion, ammonia, urea and glucose levels and hematologic parameters. Comp Biochem Physiol A Physiol. 1996; 113:375-81.

Le Ruyet JP, Boeuf G, Infante JZ, Helgason S, Le Roux A. Short-term physiological changes in turbot and seabream juveniles exposed to exogenous ammonia. Comp Biochem Physiol A Mol Integr Physiol. 1998;119:511-8.

Liang Z, Liu R, Zhao D, Wang L, Sun M, Wang M, Song L. Ammonia exposure induces oxidative stress, endoplasmic reticulum stress and apoptosis in epatopancreas of pacific white shrimp (Litopenaeus vannamei). Fish Shellfish Immunol. 2015;54:523-8. 
Paust LO, Foss A, Imsland AK. Effects of chronic and periodic exposure to ammonia on growth, food conversion efficiency and blood physiology in juvenile Atlantic halibut (Hippoglossus hippoglossus L.). Aquaculture. 2011;315:400-6.

Person-Le Ruyet J, Lamers A, Roux AL, Severe A, Boeuf G, Mayer-Gostan N. Longterm ammonia exposure of turbot: effects on plasma parameters. J Fish Biol. 2003;62:879-94.

Thangam Y, Perumayee M, Jayaprakash S, Umavathi S, Basheer SK. Studies of ammonia toxicity on haematological parameters to freshwater fish Cyprinus carpio (common carp). Int J Curr Microbiol App Sci. 2014;3:535-42.

Vinodhini R, Narayanan M. The impact of toxic heavy metal on the hematological parameters in common carp (Cyprinus carpio L.). Iran J Environ Health Sci Eng. 2009;6:23-8.

Wendelaar Bonga SE. The stress response in fish. Physiol Rev. 1997;77:591-625.

\section{Submit your next manuscript to BioMed Central} and we will help you at every step:

- We accept pre-submission inquiries

- Our selector tool helps you to find the most relevant journal

- We provide round the clock customer support

- Convenient online submission

- Thorough peer review

- Inclusion in PubMed and all major indexing services

- Maximum visibility for your research

Submit your manuscript at www.biomedcentral.com/submit 